\title{
Strategi Pemenangan Partai Demokrasi Indonesia Perjuangan pada Pemilu Tahun 2019 di Kabupaten Aceh Tengah
}

\author{
Nofriadi, Effendi Hasan, Ubaidullah, Helmi
}

Universitas Syiah Kuala, Banda Aceh, Indonesia

\begin{tabular}{|c|c|}
\hline ARTICLE INFORMATION & A B S T R A C T \\
\hline $\begin{array}{l}\text { Received: July 26, } 2021 \\
\text { Revised: September 14, } 2021 \\
\text { Accepted: October 25, } 2021 \\
\text { Available online: October 31, } 2021\end{array}$ & \multirow{5}{*}{$\begin{array}{l}\text { A political party is a political organization that adheres to and is based on a certain ideology or can also be } \\
\text { interpreted as an organization that accommodates the interests and voices of the people who want their interest } \\
\text { to be heard by the authorities. Political marketing and political strategy are the most important part of selling } \\
\text { and getting a positive response from the community so that people support certain parties or certain candidates. } \\
\text { The research method with a qualitative approach, this strategy or method of winning has been thought out and } \\
\text { also planned long before the election day arrives, but this strategy is also inseparable from the cooperation and } \\
\text { contribution of the political parties it carries in achieving common goals. there are several ways and strategies } \\
\text { carried out by the PDI-P party in the 2019-2024 period and it became one of the extraordinary events so that the } \\
\text { PDI-P party won with the most votes. The strategy carried out by the PDI-P party in Central Aceh Regency is } \\
\text { the collaboration between legislative candidates and the community. Cooperation carried out by the PDI-P } \\
\text { party legislative candidates is one very good way to do it, so that work plans through the voice of the community } \\
\text { can be carried out easily because of this collaboration. The next strategy is to improve good communication with } \\
\text { the community, increase socialization, and have a competition event held by the PDI-P party to the community } \\
\text { With the competition event held by the PDI-P party legislative candidates to the community, so that people know } \\
\text { more about the nature, character, behavior and know more about who the legislative candidates are. As well as } \\
\text { improving the system and the way the PDI-P party's legislative candidates campaign openly and privately }\end{array}$} \\
\hline KEYWORDS & \\
\hline $\begin{array}{l}\text { Elections, PDI-P Party, Legislative Candidates, Aceh } \\
\text { Tengah }\end{array}$ & \\
\hline CORRESPONDENCE & \\
\hline $\begin{array}{l}\text { Nama: Nofriadi } \\
\text { E-mail: nof.salur@gmail.com }\end{array}$ & \\
\hline
\end{tabular}

\section{PENDAHULUAN}

Partai politik merupakan salah satu organisasi politik yang didalamnya menganut dan berprinsip pada sebuah ideologi tertentu atau bisa juga diartikan sebagai organisasi yang mewadahi kepentingan dan suara rakyat yang menginginkan kepentingannya dapat didengar oleh penguasa (Anggara, n.d.; Budiardjo, n.d.). Pada sisi etimologis ada seorang ahli bernama Maurice Duverger (2005) mendeklarasikan bahwa kata partai itu berasal dari bahsa latin yaitu pars atau dapat diartikan sebagai "Bagian". Dengan pengertian dari Maurice Duverger tersebut maka kita bisa memahami bahwa partai ini ialah suatu bagian yang berimplikasi pada begian bagian yang lain secara kompleksitas dan terstrukur. Oleh dari pernahaman tersebut tentu disebuah negara tidak akan bisa menganut asas partai tunggal sebab tidak bisa menganut unsur-unsur bagian tertentu yang sangat kompleks (Katz S Richard dan Crotty William, 2015; Labolo, M., 2015).

Dalam memberikan informasi komunikasi, partai dapat menggunakan berbagai peralatan pemasaran termasuk profil pemilih, segmentasi, targeting dan e-marketing (Lilleker, 2006). Mereka juga dapat menanggapi keterangan pasar dalam cara mereka merangkakan produk politik yang mereka tawarkan, fokus untuk menjadi orientasi pasar daripada orientasi penjualan (parties can utilize a range of marketing tools including voter profiling, segmentation, micro-targeting and e-marketing to inform their communication. They can also respond to market intelligence in the way they design the political product they offer, becoming market-oriented rather than primarily sales-oriented) (Less, M., Jennifer, Stromback, Jesper dan Rudd, 2009). Selain itu, salah seorang ahli Hukum
Tata Negara indonesia sekaligus mantan ketua mahkamah konstitusi indonesia yaitu Jimly Asshiddiqie juga mempunyai pendapat mengenai asal muasal partai ini. Beliau berpandangan bahwa partai merupakan asal mula dari bahasa inggris yaitu part, yang bisa diartikan juga sebagai "Golongan" (Jimly Asshiddiqie, 2015).

Dalam pengertian bahasa inggris pun bisa juga part diartikan sebagai bagian namun tergantung daripada penempatan kata dan konteksitas kalimat sehingga part yang dimaksud bisa juga diartikan bagian. Menurut pemahaman Jimly Asshiddiqie (2015) golongan dalam hal partai ini menjurus pada pengelompokan masyarakat berdasarkan kesamaan tertentu misalnya kesamaan ideologi, kesamaan agama, kesamaan ras, kesamaan suku, bahkan kesamaan kepentingan yang direncanakan. Penggolongan ini bentuknya menjadi organisasi secara umum namun dapat didiferensiasikan menurut letak lingkungan aktifitasya. Oleh karena itu, dalam hal ini partai maka wilayah aktifitasnya berada pada organisasi politik yang sudah tentu tujuan utama nya ialah bergerak di bidang politik secara luas (Nursal, 2004). Maka identiknya partai akan berhubungan dengan keperpolitikan di berbagai daerah dan lingkup masyarakat secara langsung maupun tidak langsung (Firmanzah, 2008).

Setelah pengesahan UUPA di Provinsi Aceh, masyarakat Aceh sendiri dapat mendirikan partai politik lokal di Aceh, sebagaimana diatur dalam Peraturan Pemerintah Indonesia Nomor 20 Tahun 2007 tentang Partai Politik Lokal di Aceh. (vivajusticia.law.ugm.ac.id, 2021). Kehadiran Partai Politik Lokal juga mempengaruhi kemenangan bagi partai nasional (Labolo, M., 2015), hal ini terbukti ketika hasil pemilu di Aceh 
pada saat itu, Partai lokal mampu mendapat dukungan dengan perolehan suara yang sangat dominan dari rakyat Aceh, hal ini dapat dilihat dari peroleh suara Partai Aceh di Dewan Perwakilan Rakyat Aceh (DPR Aceh), dari 69 kursi yang ada, PA memperoleh Sebanyak 33 Kursi (47\%) ditambah Partai Daulat Aceh 1 Kursi (1.4\%) Kemenangan partai lokal pada pemilu 2009 di Aceh tidak hanya pada tingkat provinsi, tetapi juga diikuti oleh kabupaten dan kota. Akan tetapi dengan berbagai strategi yang dilakuka partai PDIP yang terjadi di Aceh tengah justru sebaliknya (Komisi Independen Pemilihan Aceh, 2011).

Di Provinsi Aceh telah banyak terbentuknya partai politik baik itu partai politik yang bersifat nasional maupun partai politik yang bersifat lokal. Pada pesta demokrasi tahun 2019 tercatat bahwa ada 16 partai politik nasional yang telah lolos untuk mengikuti Pemilu pada tahun tersebut. Namun ada 4 partai yang bersifat lokal di provinsi aceh yang memiliki nomor urut dari 15 sampai 18 dan bertarung pada kanca daerah aceh pada bagian legislatif di tingkat provinsi dan kabupaten maupun eksekutif di tingkat provinsi maupun kabupaten/kota. Tentu di provinsi Aceh sendiri menjadi satu kontestasi politik yang sangat sengit sebab begitu banyaknya partai lokal yang juga mengeluarkan kandidatnya untuk memperebutkan kursi DPRK ataupun DPRA serta Gubernur dan Bupati/Walikota (Angreni, 2021). Tentu ada banyak hal dan aspek yang dilakukan untuk memenangkan kontestasi demokrasi tersebut.

Dilain sisi, aceh merupakan daerah bekas konflik yang mana dulu pernah terjadi pemberontakan oleh Gerakan Aceh Merdeka atau GAM yang mana peristiwa pemberontakan GAM terjadi pada masa kepresidenan Megawati Soekarno Putri yang mana Megawati Soekarno Putri sendiri sekarang menjadi ketua umum daripada partai demokrasi indonesia perjuangan atau PDIP (Aliabbas, 2008). Aceh sebagai daerah bekas konflik tentu memiliki masa kelam dan dendam tersendiri secara personal kepada pihak pihak yang terkait dalam konflik tersebut terutama pemerintah pusat. Paradigma paradigma yang tertanam dalam benak masyarakat aceh sendiri bagaimana sikap dan tindakan presiden megawati selama ia menjabat sebagai presiden dan mengambil tindakan terhadap masyarakat aceh terkhusus pemberontakan GAM tersebut. Tidak tanggung-tanggung hingga sekarang pun secara mayoritas stereotipe terhadap PDIP ataupun Megawati masih saja berbekas di benak masyarakat Aceh. Berbagai pemikiran buruk langsung tergambarkan jika dikaitkan dengan PDIP maupun Megawati sendiri selaku ketua umum dari partai tersebut. Meskipun PDIP partai besai secara nasional akan tetapi untuk memenangkan pemilu di Aceh sangat sulit termasuk di Aceh tengah. Ini menjadi satu faktor tersendiri dari pada kesuksesan PDIP di provinsi Aceh maupun di kabupaten yang ada diAceh sebab secara history Aceh adalah wilayah dan daerah yang sangat berdarahkan islam dalam hal kehidupan bermasyarakat khususnya dalam hal keperpolitikan juga. PDIP mempunya citra buruk secara umum di benak masyarakat aceh itu sendiri (Aliabbas, 2008). Oleh karenanya hal hal fundamental ini menjadi poin dan prinsip penting untuk kemenangan partai politik PDIP ini sendiri.

Pada Pemilu tahun 2019 yang telah dilaksanakan, PDIP menduduki posisi ke 10 suara terbanyak di Aceh berdasarkan data hasil rekapitulasi KPU dan disetujui oleh KIP yang mana posisi pertama dipegang oleh partai demokrat, lalu disusul oleh partai gerindra dan urutan ketiga ialah partai golkar. Secara keseluruhan suara yang diperoleh oleh PDIP pada pilkada legislatif tahun 2019 berjumlah 111.381 suara. Tentu jumlah ini sangatlah jauh dengan perolehan jumlah suara dari partai demokrat selaku peraih suara tertinggi di aceh yaitu 413.438 suara yang disusul oleh partai gerindra pada posisi ke dua yang memperoleh suara sebanyak 376.784 suara. Dari data diatas jelas secara keseluruhan PDIP kalah di keseluruhan provinsi (Thaha, 2018).

Namun, jika kita melihat data dari hasil rekapitulasi data KIP pada Kabupaten Aceh Tengah sendiri, PDIP memperoleh suara yang sangat signifikan yakni 15.362 suara. Hal ini menjadi satu perhatian tersendiri sebab diwilayah Provinsi Aceh Kabupaten Aceh Tengah malah mendapatkan perolehan suara yang mendominasi dari partai lainnya. Oleh sebab itu maka kita akan melihat kondisi ini menjadi satu poin bahwa apakah sejarah masa kelam itu sudah bisa dilupakan dan dimaafkan oleh masyarakat Aceh Tengah ataupun kinerja daripada anggota kandidat yang berasal dari partai PDIP itu bekerja dengan maksimal dan benar benar menerima aspirasi rakyat dengan penuh tanpa adanya tumpang tindih dan perbedaan bahasa ras dan agama.

Kemudian, para anggota legislatif yang berasal dari PDIP Aceh Tengah ini, merupakan para-para tokoh publik yang memiliki latar belakang serta pengalaman yang hebat, sehingga uniknya, para anggota legislatif yang berasal dari PDIP Aceh Tengah ini, dapat memberikan kontribusi yang sangat besar untuk kemenangan partai PDIP di kabupaten Aceh Tengah ini.

Tujuan dari penulisan ini adalah mengetahui dan menjelaskan bagaimana rencana strategis yang dilakukan oleh partai PDIP Aceh Tengah, sehingga dapat memberikan kontribusi besar terhadap pihak legislatif dengan memperoleh suara terbanyak di kabupaten Aceh Tengah ini.

Penelitian ini berbeda dengan penelitian kepartaian lainnya. Hal ini dikarenakan adanya multifaktor yang krusial dalam melihat kemenangan dari sebuah partai di provinsi aceh. Biasanya dalam penelitian tentang kepartaian di aceh selalu mengarah pada eksistensi dan kinerja petugas partai yang terkadang bekerja diluar kepentingan masyarakat. Namun pada penelitian ini mengarah pada kesuksesan strategi dari petugas partai dan jajarannya dalam meraih suara pada kontestasi pesta demokrasi.

\section{METODE}

Adapun dalam meneliti mengenai strategi kemenangan partai PDIP pada pilkada legislatif tahun 2019 menggunakan metode penelitian kualitatif dengan metode deskriptif (Almanshur Fauzan, 2012; Bungin, 2007). Langkah-langkah metode kualitatif adalah, menyusun rancangan penelitian. Metodologi adalah proses, prinsip, dan prosedur yang kita gunakan untuk mendekati problem dan mencari jawaban (Mulyana Deddy, 2008). Menurut Sugiyono (2015), metode ialah sebuah penelitian yang direalisasikan pada objek alamiah, di mana peneliti sebagai instrumen kunci (Dantes, 2012). Langkah pertama metode dalam penulisan ini yaitu menentukan kerangka dan rancangan dalam menentukan judul, sehingga menghasilkan judul "Strategi Pemenangan Partai Demokrasi Indonesia Perjuangan Pada Pemilu Tahun 2019 di Kabupaten Aceh Tengah". Kemudian langkah selanjutnya yaitu menentukan Lokasi dalam membuat tulisan ini. 
Lokasi yang didapatkan dalam membuat tulisan ini yaitu di Kantor DPRK Aceh Tengah yang beralamat di Jl. Yos Sudarso No. 10 Takengon, Lut Tawa, Kabupaten Aceh Tengah. Adapun teknik pengumpulan data Melalui observasi dan wawancara serta dari buku-buku, atau artikel, yang relevan. Selain itu juga menganalisis data hasil rekapitulasi yang dikeluarkan oleh KPU Kabupaten Aceh Tengah yang sudah terdiri secara lengkap mengenai perolehan suara dari setiap daerah pemilihannya dan dari setiap partai partai politik yang ada. Adapun yang menjadi informan dalam penelitian ini anggora legislatif kabupaten (DPRK), pengurus partai politik dan masyarakat di kabupaten Aceh tengah untuk mendapatkan keterangan lebih lanjut mengenai aspek yang penting guna mendapatkan hasil yang maksimal dalam penelitian. Maka dalam penelitian ini menggabungkan antara data sekunder dan data primer yang mana dapat menguatkan data data pada penelitian ini. Dalam penelitian ini mengunakan Teknik analisis data meliputi data reduction, data display dan conglusion drawing/varification (Sugiyono, 2012)

\section{HASIL DAN PEMBAHASAN}

Marketing Partai Demokrasi Indonesia Perjuangan (PDI-P) pada Pemilihan Umum Legislatif tahun 2019 di Kabupaten Aceh Tengah

Dengan menciptakan segmentasi, dapat mencakup seluruh segmen dengan program pencitraan yang dimiliki. Efektivitas pencitraan harus dijalankan dengan menetapkan target audience yang akan menjadi sasaran program (Wesesa, 2011). Setiap partai dan kandidat memiliki streotipe sendiri di lingkungan di mana ia bergerak. Streotipe tersebut merupakan gambaran yang ada dalam bayangan masyarakat atau pemilih tentang partai atau kandidat, pada periode tertentu. Terkadang gambaran ini hampa, sehingga masyarakat atau pemilih belum mengenal partai atau kandidat. Melalui target image ini kita merencanakan strategi, membangun streotipe yang baik dan positif. Dengan tema yang lebih baik, solusi yang lebih, penawaran figur yang lebih baik dan kompetensi yang lebih baik pula (Schroder, 2010).

Membangun citra partai tidak cukup hanya dalam waktu yang singkat, tetapi untuk membangun citra partai butuh waktu yang panjang, citra dibangun oleh tokoh dan partai politik di Masyarakat, ketika tokoh partai politik masuk dalam pemerintahan mendapat prestasi atau memiliki kinerja positif, maka akan berdampak kepada partai politik dengan mendapatkan dukungan dari masyarakat, begitu juga sebaliknya, kalau kinerja tokoh partainya negatif maka akan berdampak buruk terhadap partai politik dengan kehilangan dukungan dari masyarakat, seperti partai PDIP mendapat dukungan masyarakat ketika Jokowi terpilih menjadi gubernur DKI Jakarta dan terpilih menjadi presiden. Dua periode Jokowi menjadi presiden sehingga mendapatkan respon positif dari masyarakat untuk partai PDIP menjadi pemenang selama dua kali berturut-turut yaitu Pemilu 2014 dan 2019, sebaliknya partai Demokrat mendapat nilai negative di periode kedua partai Demokrat berkuasa ketika tokoh-tokoh partainya banyak terjerat korupsi, sehingga membuat citra partai mengalami penurunan secara drastis, maka membangun citra partai tidak bisa dengan waktu singkat melainkan dengan waktu yang panjang.

"Pemilu tahun 2019 di Aceh Tengah, Partai Demokrasi Indonesia Perjuangan (PDIP) telah melakukan berbagai macam strategi yang dilakukan untuk mendapat dukungan dari masyarakat yang punya hak pilih, Partai Demokrasi Indonesia Perjuangan (PDIP) dan kandidat calon anggota legislative di Kabupaten Aceh Tengah memiliki beberapa cara, Partai dan kandidat harus memiliki citra yang positif agar pemilih dapat lebih meyakinkan hatinya untuk memilih partai PDIP, dan itu sudah dilakukan oleh Parti Demokrasi Indonesia Perjuangan (PDI-P) Kabupaten Aceh Tengah dengan mendapatkan dukungan dari masyarakat yang sangat luar biasa sehingga mendapatkan suara terbanyak dibandingkan dengan partai lainnya, baik local maupun nasional." (Wawancara dengan Bapak Samsuddin Anggota DPRK Aceh Tengah dari PDIP, 27 Juli 2021).

Citra Partai Demokrasi Indonesia Perjuangan (PDIP) Kabupaten Aceh Tengah mendapatkan respon positif dengan citra sebagai partai wong cilik, mendapatkan suara terbanyak dibanding dengan partai politik lain, baik lokal maupun Nasional. Kemenangan Partai Demokrasi Indonesia Perjuangan (PDIP) tidak terlepas dari kerja keras pengurus partai dan calon anggota legislative dari PDIP untuk terus mengkampanyekan program partai dan calon kandidat yang diajukan partai pada Pemilu tahun 2019 di Kabupaten Aceh Tengah.

Pertama, Produk (Product). Niffengger memisahkan produk politik menjadi 3 bagian yaitu platform partai, masa lalu kandidat, dan karakteristik pribadi kandidat. Inti fokus dari partai politik tentuny adalah platform atau paradigma partai yang terdapat konsep partai, identitas ideologis dan visi misi dari partai politik, serta program kerja kedepan dari partai politik tersebut. Kedua.Promosi (Promotion, Didalam sistem marketing politik ini haurs menggunakan promosi sebagai alat yang berfungsi untuk "menjual" produk politik yaitu pasangan calon. Ketiga, Harga (Price). Didalam marketing ini konsep harga mencakup beberapa segi yaitu dimulai dari ekonmis, citra psikologis hingga citra nasional (Sutrisno, Yuningsih, N., 2018). Dari segi harga ekonomis yang dimaksud adalah banyaknya dana kampanye yang digunakan selama masa periode kampanye dari calon kandidiat tersebut. Keempat, Tempat (Place).Tempat dalam teori marketing politik mengacu pada bagaimana calon kandidat dapat memaksimalkan kefektifan setiap langakah dalam kampanye maupun promosi dari dirinya agar diketahui oleh banyak orang. Kampanye politik yang dilakukan oleh calon kandidat harus bisa menyentuh seluruh lapisan dan elemen masyarakat.

Selain dari melakukan citra yang positif bagi pemilih, ada empat aspek yang harus dilakukan partai ataupun kandidat calon anggota legislatif dari Partai Demokrasi Indonesia Perjuangan (PDI-P) Aceh Tengah. Yang pertama adalah produk partai politik seperti halnya platform partai, masa lalu kandidat, dan karakteristik pribadi kandidat, Partai Demokrasi Indonesia Perjuangan (PDI-P) dengan platform yang sangat jelas yaitu membantu masyarakat kecil atau sering disebut sebagai partainya wong cilik yang terus memperjuangkan aspirasi masyarakat kecil untuk disampaikan kepada pemerintah setempat, selain itu partai juga punya program membantu masyarakat atau pemilih melalui daerah pemilihan dari masing-masing anggota Dewan Perwakilan Rakyat Kabupaten (DPRK) Aceh Tengah yang terpilih. Selanjutnya Partai Demokrasi Indonesia Perjuangan (PDI-P) Aceh Tengah juga menyeleksi semua calon anggota legislative dengan melihat berbagai pertimbangan salah satunya masa lalu kandidat, dengan melihat hal tersebut sehingga partai muda untuk mengkampanyekan calon kepada pemilih., PDIP Aceh Tengah 
muda untuk mengambil hati pemilih dengan mengandalkan calon anggota legislatif dengan meminimalisir masa lalu kandidat yang ditawarkan kepada masyarakat.

Kemudian poin yang kedua adalah promosi, dimana Partai PDIP harus menjual produknya dengan cara mempromosikan program partai dan memperkenalkan calon kandidat anggota legislative Aceh Tengah kepada masyarakat, seperti penjelasan diatas produk harus bisa diterima masyarakat pemilih, partai telah menggunakan berbagai macam cara untuk lebih muda mempromosikan partai dan kandidat kepada masyarakat, seperti kampanye terbuka dan tertutup melalui dialogis kemudian membuat baliho, stiker, kalender, dan membagikan program partai PDIP kepada masyarakat agar pemilih dapat memahami apa tujuan dari partai PDIP dan para calon kandidat, sehingga memudahkan partai PDIP mendapatkan suara pemilih untuk memilih partai ataupun kandidat yang dijual.

Poin ketiga adalah harga, dimana harga yang dimaksud adalah biaya kampanye atau dana kampanye, sebagai partai pemenang secara nasional pada Pemilu tahun 2014, partai PDIP sangat siap untuk bertarung dengan partai lain, baik partai lokal ataupun partai nasional, persiapan dana kampanye tidak ada persoalan dengan biaya atau anggaran. Dari masing-masing kandidat calon anggota legislative dari partai PDIP membuat semacam laporan keuangan untuk biaya kampanye dan PDIP Aceh Tengah juga memiliki keuangan partai yang diambil dikutip dari pengurus partai ataupun dari anggota dewan terpilih, dengan demikian pengurus partai tidak ada masalah dari segi dana kampanye, sehingga kemenangan partai PDIP pada Pemilu tahun 2019 di Kabupaten Aceh Tengah juga tidak terlepas dari kesiapan biaya kampanye untuk memudahkan Pemilih mengenal calon yang akan dipilih dari partai PDIP tersebut.

Terakhir atau yang keempat adalah tempat, partai PDIP harus memastikan calon kandidat yang telah dicalonkan harus melihat tempat atau situasi dari daerah tersebut agar memudahkan para kandidat menyampaikan program partai ataupun program kandidat sehingga lebih banyak yang mendengarkan penyampaiannya maka lebih gampang untuk masyarakat memilih kandidat dari partai PDIP. Pada Pemilu tahun 2019 partai PDIP telah membagi segmentasi pemilih, dimana wilayah-wilayah dengan basis massa pemilih dari PDIP itu sendiri, sehingga dengan melihat dari segmentasi memudahkan kandidat ataupun partai mengumpulkan pemilih untuk mendengarkan penyampaian dari kandidat kepada pemilih, dengan melakukan hal tersebut PDIP Kabupaten Aceh Tengah dapat meraup suara yang signifikan terutama di Dapil 2 dengan perolehan 2 kursi, sehingga dianggap efektif melakukan segmentasi pemilih dalam menyampaikan program partai ataupun kandidat. Bentuk dari pembagin ini ialah dengan melihat wilayah wilayah yang memiliki potensi pendukung yang kuat.

Pemilu tahun 2019 menjadi kemenangan partai PDIP di Kabupaten Aceh Tengah, keunggulan partai adalah salah satunya dengan mengkampanyekan PDIP sebagai partainya wong cilik dan yang paling efektif adalah peran dari setiap calon anggota legislative yang aktif turun kelapangan untuk mempromosikan diri mereka dan partai politik yang mengusung mereka, artinya kemenangan partai PDIP di Kabupaten Aceh Tengah bagian dari strategi tim untuk melakukan kampanye baik secara terbuka maupun secara tertutup secara dialogis.

\section{Strategi Politik PDIP Kabupaten Aceh Tengah}

Stategi politik menurut pendapat Schroder (2013) mengacu pada tata cara yang dilakukan untuk melaksanakan cita-cita politik. Strategi tentu memiliki dampak dari langkah-langkah yang dilakukan yang bermaksud untuk mencapai seluruh tujuan tujuannya. Stategi memiliki tujuan untuk mencapai kemenangan dalam setiap pertarungan atau perlombaan. Maka kemenangan akan menjadi konse fokus dari strategi didalm perolehan suara maupun dalam banyaknya perolehan kursi di kontestasi tersebut.

Dalam sebuah pertarungan politik harus memiliki strategi yang matang untuk mencapai kemenangan, karena lawan politik punya berbagai macam cara untuk meraup suara pemilih untuk memilih partai ataupun kandidat yang ajukan kepada masyarakat, dengan demikian partai politik tidak cukup hanya menggunakan baliho untuk bias dibaca masyarakat, tetapi partai harus keras untuk turun langsung ke bawah mendengarkan aspirasi masyarakat untuk bias dijadikan bahan masukan ketika nanti menjawab sebagai anggota Dewan Perwakilan Rakyat Kabupaten (DPRK). Partai PDIP Kabupaten Aceh Tengah tidak lengah dari evoria kemenangan Pemilu tahun 2014 secara nasional, tetapi partai terus berbenah untuk menyiapkan strategi jitu untuk lebih gampang diterima masyarakat secara keseluruhan di Kabupaten Aceh Tengah khususnya di daerah basis PDIP itu sendiri. Maka dapat diuraikan berbagai macam strategi yang telah dilakukan oleh partai PDIP Kabupaten Aceh Tengah pada Pemilu tahun 2019. Seperti yang terdapat pada Peraturan Dewan Perwakilan Rakyat Aceh Tengah Nomor 1 tahun 2019 Tentang Tata Tertip, yang telah mengedepankan kepentingan masyarakat dalam setiap perjuangan di Dewan Perwakilan Rakyat Kabupaten (DPRK) untuk disampaikan kepada pemerintah sehingga memunculkan kepercayaan masyarakat kepada partai PDIP. Ada beberapa strategi yang dilakukan partai PDIP.

\section{Sering Melakukan Sosialisasi Ideologi Partai Kepada Masyarakat}

"Kami terus mensosialisasi ideologi partai PDI-P untuk menjelaskan bahwa harus adanya perjuangan dalam memperjuangkan masyarakat yang tertindas. Tentunya ini berasal dari rincianyang ada melalui ideologi pancasila. dengan adanya peningkatan penjelasan ideologi partai ini, masyarakat lebih mengetahui bagaimana perkembangan yang berasal dari ideologi pancasila tersebut. Sehingga masyarakat dapat mengetahui penjelasan tentang partai politik dan strategi yang benar dalam melakukan strategi kemenangan. Penjelasan ideologi partai sangat penting untuk diketahui masyarakat, ideologi bagian terpenting dalam sebuah partai politik, partai PDIP sangat serius dalam hal ideologi partai, karena partai PDIP menganut sistem partai ideologi atau partai kader bukan partai massa. Setiap kader partai harus memahami ideologi partai dengan mengedepankan kepentingan rakyat diatas kepentingan kelompok atau golongan. Partai PDIP terus melakukan sosialisasi kepada masyarakat dengan menyampaikan ideologi partai sebagai bagian dari strategi untuk mendapatkan dukungan dari masyarakat." (Hasil Wawancara dengan Bapak Arwin Mega Anggota DPRK Aceh Tengah, 26 Juli 2021)

Peningkatan Mutu Pendidikan Masyarakat

Strategi ini menunjukan bahwa PDI-P Kabupaten Aceh Tengah ini, memiliki strategi dalam bidang pendidikan. Sehingga dengan adanya peningkatan mutu pendidikan, para masyarakat akan lebih mengetahui dan juga lebih mengenal 
bagaimana cara berdemokrasi yang benar, dan memilih pemimpin yang baik. Kami juga memperjuangkan dibidang pendidikan, karena pendidikan bagian yang terpenting dalam sebuah daerah, apalagi didaerah Aceh Tengah masih membutuhkan peningkatan pendidikan, makanya program pendidikan menjadi prioritas utama partai PDIP di Aceh Tengah dan nasional secara keseluruhan. Makanya kami setiap calon anggota legislative harus menyampaikan kepada masyarakat mengenai perlunya pendidikan bagi anak, karena pendidikan menjadi salah factor dalam kemajuan sebuah bangsa, makanya kami semua bergotong royong dalam menyampaikan kepada masyarakat untuk dapat dukungan dari pemilih untuk dapat memilih partai PDIP, Alhamdulillah dengan semangat gotong royong semua caleg dan kader partai, maka PDIP Aceh Tengah menjadi partai pemenang.

\section{Peningkatan Silaturahmi Dengan Masyarakat}

"Silaturahmi yang dilakukan dengan masyarakat merupakan hal sangat penting. Karena tanpa masyarakat kemenangan yang di rencanakan akan mustahil terjadi. Dengan menjalin tali persaudaraan ini, maka masyarakat juga akan lebih mengenal siapa dan bagaimana sosok tokoh dari calon legislatif tersebut. Salah satu strategi dalam peningkatan silaturahmi yang dilakukan oleh partai PDIP Aceh Tengah ini dikenal dengan istilah "Ngupi Murum" Istilah ini dapat diartikan sebagai pertemuan yang dilakukan oleh calon legislatif dari PDIP Aceh Tengah ini dengan cara ngopi bersama masyarakat. Dengan seringnya melakukan pertemuan atau silaturahmi kepada masyarakat akan berdampak positif bagi partai, karena semua kader partai mendengarkan secara langsung aspirasi dari masyarakat. Memang di Aceh Partai PDIP kurang disukai masyarakat secara luas, disebabkan adanya isu-isu negative yang dimainkan oleh partai politik yang lain untuk menjatuhkan partai PDIP di Aceh, banyak sekali isu negative tentang partai PDIP, salah satunya mengenai PKI.Partai PDIP adalah partainya PKI kemudian PDIP partai anti islam. Dari isu-isu itu membuat partai PDIP di Aceh tidak mendapat respon positif dari masyarakat karena masyaraka disuguhkan dengan isuisu negative tentang PDIP. Makanya program partai PDIP di Aceh Tengah salah satunya dengan sering turun ke bawah bersilaturahmi dengan masyarakat dan tokoh-tokoh masyarakat untuk menjelaskan dan mendengarkan aspirasi masyarakat." (Hasil Wawancara dengan Bapak Arwin Mega Anggota DPRK Aceh Tengah, 26 Juli 2021)

\section{Strategi Pemenangan}

Strategi yang dilakukan ini merupakan salah satu strategi yang dilakukan oleh Partai Demokrasi Indonesia Perjuangan (PDIP) Kabupaten Aceh Tengah. Strategi politik dapat dikatakan dengan pemasaran politik. Maksudnya adalah konsep yang bersifat permanen yang harus dilaksanakan oleh sebuah partai politik, para politikus, dan para anggota lainnya guna untuk membangun kepercayaan dari publik. Tentunya hal ini dijalankan dengan melibatkan seluruh aspek petugas partai tersebut.

\section{Kaderisasi}

Kaderisasai merupakan calon-calon regenerasi yang akan melanjutkan tongkat estafet dari PDI-P. Para kaderisasi ini akan dilatih dan dipersiapkan beberapa ilmu sehingga memiliki kemampuan untuk meningkatkan sistem kinerja dan visi misi yang direncanakan oleh PDI-P Aceh Tengah ini. dengan adanya strategi marketing politik yaitu mencari kaderisasi ini, maka strategi akan berjalan lebih maju, karena para kaderisasi tersebut akan memperjuangkan kemenangan partai PDI-P kepada seluruh desa yang ada di kabupaten Aceh Tengah ini (Salang, 2007). Seperti penjelasan diatas, partai PDIP tidak sembarang untuk merekrut kader-kader nya, karena setiap kader akan dipersiapkan untuk menduduki jabatan-jabatan publik, seperti menjadi anggota legislatif dan maupun di eksekutif. Makanya partai PDIP merupakan partai kader yang punya ideologi Pancasila.

\section{Membangun Komunikasi yang Baik di Internal Partai PDIP}

Membangun komunikasi yang baik di internal partai, merupakan salah satu faktor keberhasilan dalam meraih hasil yang puas. Koalisi ini dilakukan agar tidak terjadinya kesalahpahaman dalam berkomunikasi (Miss communication) dalam menghadapi pemilu legislatif ini. Hal ini dilakukan agar para pengurus yang ada di partai tersebut tidak beralih memberikan dukungan kepada partai yang lain. Kemudian, adanya koalisi ini yaitu agar kerja sama antar partai akan lebih dekat dan lebih solid. Semua ini dilakukan untuk bisa satu suara dalam memperjuangkan partai PDIP dalam meraih kemenangan di Kabupaten Aceh Tengah, karena ada juga partai, dia belum berperang sudah berkonflik di internal partai itu sendiri, jadi bagaimana kita bias menang kalau semua kader tidak satu suara untuk berjuang meraih kemenangan, makanya di internal partai PDIP Aceh Tengah sangat mengedepankan atau membangun komunikasi yang baik di dalam partai. Jadi kalau sudah satu suara, maka lebih gampang untuk turun ke masyarakat, tidak ada yang berbeda dalam menyampaikan program-program partai. Mulai dari tingkat DPC (Dewan Pimpinan Cabang), PAC (Pengurus Anak Cabang) serta PACR (Pengurus Anak Cabang Ranting)

\section{Membangun Koalisi Internal dan Membangun Koalisi Eksternal}

Koalisi internal ini merupakan kerja sama yang dilakukan antara pimpinan partai di tingkat kabupaten dengan pimpinan cabang baik di tingkat kecamatan, dan desa. Hal ini dilakukan dengan cara sering melakukan musyawarah dan membahas bagaimana rencana serta strategi yang akan dilaksanakan untuk mencapai kemenangan. Kerja sama ini juga harus memiliki tanggung jawab yang sangat besar, baik dari pimpinan partai tingkat kabupaten, maupun pimpinan partai tingkat kecamatan, dan desa. Tanggung jawab ini diberikan kepada para pengurus maupun calon legislatif dengan memperhatikan ketentuan yang berlaku (Thaha, 2018).

Koalisi internal PDIP Aceh Tengah ini merupakan koalisi yang diikuti oleh seluruh anggota partai baik dari kader kalangan muda, maupun dari kalangan tua. Kerjasama yang dilakukan pada bagian internal ini dilakukan dengan cara bermusyawarah antara satu dan lainnya. Para koalisi internal saling mendengar dan memberikan pendapat untuk kemenangan partai PDIP di kabupaten Aceh Tengah. kemudian, PDIP Aceh Tengah ini juga memiliki koalisi internal yang berasal dari kalangan tua, kalangan tua ini memiliki wewenang sebagai penasehat guna untuk kebaikan PDIP Aceh Tengah.

Koalisi eksternal merupakan kerja sama yang dilakukan para pendukung dan tim sukses dengan mengikut sertakan para perangkat desa, para organisasi sumber daya masyarakat, serta para relawan pendukung. Perangkat desa ini juga dilibatkan sebagai tim sukses untuk dapat mempertahankan dan memastikan bahwa calon legislatif yang berasal dari PDI-P ini layak untuk dipilih dan dijadikan wakil rakyat. 


\section{MembentukTim Sukses}

Partai Demokrasi Indonesia Perjuangan Kabupaten Aceh Tengah ini melalui para calon legilslatifnya, tentunya memiliki masing-masing tim dalam memenangkan pemilihan umum. Hal ini dapat dikatakan dengan sebutan "Tim Sukses". Pembentukan tim sukses atau tim pemenangan ini tentunya harus berdasarkan kepercayaan yang berasal dari para calon legislatif kepada sekelompok masyarakat. Masing-masing calon legislatif memiliki para tim sukses yang tersebar luas baik di kecamatan, maupun di desa-desa. Para tim sukses dan kader ini akan berusaha semampu mungkin untuk dapat membuat strategi sistem komunikasi politik untuk pemenangan dalam pemilu. Hal ini dapat mempengaruhi dan juga meningkatkan akuntabilitas partai dan jumlah suara pemenangan partai, sehingga dengan adanya tim sukses tersebut menjadikan Partai Demokrasi Indonesia Perjuangan (PDI-P) menjadi partai pemenang dan memperoleh suara terbanyak pada Pemilihan Umum legislatif periode 2019 - 2024 di Kabupaten Aceh Tengah.

Pada Pemilu 2019 partai PDIP di Kabupaten Aceh Tengah juga menerapkan sistem kualitas dan kuantitas calon legislatif yang merupakan kesesuaian dengan persyaratan yang ada guna untuk meningkatkan mutu serta kinerja yang diharapkan. Sedangkan kuantitas merupakan tolak ukur suatu hal yang dapat tertuju dan bermutu untuk mendapatkan sesuatu. Untuk itu, kualitas dan kuantitas dalam peningkatan calon legislatif sangat penting. Karena dengan adanya kualitas dan kuantitas tersebut, masyarakat dapat mengetahui bagaimana kepintaran dan keahlian yang dimiliki oleh calon kandidat legislatif tersebut. Salah satu cara yang dilakukan PDI-P dalam peningkatan calon legislatif ini yaitu, pemilihan calon yang berasal dari tokoh masyarakat, sehingga banyak masyarakat yang sudah mengenal dan mengetahui tentang kehidupan calon tersebut. Strategi memperkuat struktur ini merupakan strategi yang dilakukan oleh PDI-P Kabupaten Aceh Tengah guna untuk meningkatkan mutu dari partai tersebut. Oleh karena itu, pembaharuan dan penguatan struktur partai harus dilakukan. Agar dapat memberikan peluang yang besar dalam mendapatkan suara terbanyak di pemilihan umum. Dan penguatan ini dilakukan agar para pengurus partai lebih memiliki semangat serta kerja keras dalam meningkatkan nama baik PDI-P di Kabupaten Aceh Tengah (Schroder, 2010).

Perolehan Suara Partai Demokrasi Indonesia Perjuangan di MasingMasing Daerah Pemilihan

Pemilu tahun 2019 merupakan kemenangan bagi Partai PDIP di Kabupaten Aceh Tengah, berikut perolehan suara dari masing-masing calon anggota legislative dari setiap daerah pemilihan, bisa dikatakan keberhasilan partai merupakan perjuangan kader dan calon anggota legislative yang selalu turun ke bawah untuk mendengarkan aspirasi masyarakat secara langsung, kekuatan partai tidak cukup hanya di internal partai, tapi juga ada di tingkat masyarakat yang punya hak suara. Berikut disajikan tabel l. Tentang Jumlah Suara MasingMasing Calon Anggota Legislatif PDIP Dapil I

Tabel 1. Jumlah Suara Masing-Masing Calon Anggota Legislatif PDIP Dapil I

\begin{tabular}{clc}
\hline No & \multicolumn{1}{c}{ Nama Calon } & Suara Sah \\
\hline 1 & Ichwan Mulyadi & 1062 \\
2 & Almusanna, A.md & 797 \\
3 & Darmiati,S.Pd & 237 \\
4 & Husni Sarwa & 185
\end{tabular}

158 Nofriadi, et al

\begin{tabular}{clc}
5 & Gamahudi,ST & 502 \\
6 & Kasmawati.SM,S.Pd & 13 \\
7 & Rahmiati Tagore Putri,S.Psi & 604 \\
\hline & JUMLAH & 3551 \\
\hline
\end{tabular}

Sumber: KIP Aceh Tengah, diolah 2021

Tabel 1 menunjukkan bahwa suara yang diraih calon anggota legislatif dari Partai Demokrasi Indonesia Perjuangan (PDIP) Aceh Tengah, dapat dikatakan masing-masing dari calon anggota legislatif memiliki suara yang berbeda-beda, di daerah pemilihan satu hampir semua calon legislatif dari Partai Demokrasi Indonesia Perjuangan (PDIP) meraih suara terbanyak dengan angka diatas 500 suara dan hanya tiga calon legislatif yang mendapat suara dibawa 500 suara. Maka ini sebuah keberhasilan partai dan keberhasilan masyarakat yang telah memberi amanah kepada partai PDIP. Untuk daerah pemilihan satu partai PDIP hanya memperoleh satu kursi untuk bisa duduk di Dewan Perwakilan Rakyat Kabupaten (DPRK) Aceh Tengah yaitu bapak Ichwan Mulyadi dengan perolehan suara terbanyak dibanding dengan calon legislatif lainnya. Berikut disajikan pada tabel 2. Jumlah Suara Sah MasingMasing Calon Anggota Legislatif PDIP Dapil II

Tabel 2. Jumlah Suara Sah Masing-Masing Calon Anggota Legislatif PDIP Dapil II

\begin{tabular}{clc}
\hline No & \multicolumn{1}{c}{ Nama Calon } & Suara Sah \\
\hline 1 & Jihar Firdaus & 1715 \\
2 & Syekhutama & 885 \\
3 & Suryati Waas & 2172 \\
4 & Nasrullah & 437 \\
5 & Sabri & 94 \\
6 & Raisah & 5 \\
7 & Elfika,S.Pd & 3 \\
\hline
\end{tabular}

Sumber: KIP Aceh Tengah, diolah 2021

Daerah pemilihan 2 partai PDIP mendapatkan suara terbanyak, walaupun dari masing-masing calon anggota legislative ada yang berbeda jauh dari perolehan suaranya, kerja keras semua pengurus dan caleg partai, karena di dapil dua ini ada sebagian caleg hanya mendapat suara dibawah 10 , tetapi itu tidak mengurangi semangat dalam berjuang untuk meraih suara dari masyarakat. Maka dapat dilihat dari table 1.2 menunjukkan jumlah suara dari masing-masing caleg. Dari 7 orang calon anggota legislatif partai PDIP di daerah pemilihan dua, dari perolehan suara maka hanya dua orang yang mendapatkan kursi di Dewan Perwakilan Rakyat Kabupaten (DPRK) Aceh Tengah yaitu Ibu Suryati Waas dan Bapak Jihar Firdaus.

Tabel 3. Jumlah Suara Sah Masing-Masing Calon Anggota Legislatif Periode 2019-2024 dari PDIP Dapil III

\begin{tabular}{clc}
\hline No & \multicolumn{1}{c}{ Nama Calon } & Suara Sah \\
\hline 1 & Samsuddin, S.Ag,M.Pd & 1995 \\
2 & Zulfikar & 112 \\
3 & Dewi Angreani, S.Pd & 36 \\
4 & Bina Murga & 94 \\
5 & Aji Akbar & 76 \\
6 & Fadhillah, S.Pd & 21 \\
7 & Arjuna & 71 \\
8 & Masnaini & 20 \\
\hline \multicolumn{2}{c}{ JUMLAH }
\end{tabular}

Sumber: KIP Aceh Tenga, diolah 2021 
Tabel 3 menjelaskan jumlah suara sah yang didapat oleh masing-masing caleg dari Partai Demokrasi Indonesia Perjuangan (PDIP) di daerah pemilihan tiga, dari delapan caleg ikut kontestasi Pemilu tahun 2019 hanya satu orang yang memperoleh suara terbanyak yaitu bapak Samsuddin, sedang caleg yang lain tidak mendapatkan suara yang signifikan. Sehingga partai PDIP mendapat jatah satu kursi untuk bisa duduk di gedung Dewan Perwakilan Rakyat Kabupaten (DPRK) Aceh Tengah. Tabel 4. Jumlah Suara Sah MasingMasing Calon Anggota Legislatif Periode 2019-2024 dari PDIP Dapil IV

Tabel 4. Jumlah Suara Sah Masing-Masing Calon Anggota Legislatif Periode 2019-2024 dari PDIP Dapil IV

\begin{tabular}{clc}
\hline No & \multicolumn{1}{c}{ Nama Calon } & Suara Sah \\
\hline 1 & Arwin Mega & 2205 \\
2 & Ida Sumita, A.Md & 18 \\
3 & Zulfitriadi & 285 \\
4 & Suryani,S.Pd & 241 \\
5 & Ujang Suari Sulaiman & 267 \\
6 & M. Hudaidi,SE & 67 \\
7 & Idawati & 10 \\
8 & Sirli, ST & 211 \\
\hline & \multicolumn{2}{c}{ JUMLAH }
\end{tabular}

Sumber: KIP Aceh Tengah, diolah 2021

Pada tabel 4 perolehan suara Partai Demokrasi Indonesia Perjuangan (PDIP) di daerah pemilihan empat mendapat dukungan yang signifikan, bisa dilihat pada tabel diatas jumlah suara sah sebanyak 3.499 suara, artinya dengan perolehan suara tersebut belum juga bisa mendapat lebih dari satu kursi untuk daerah pemilihan empat. Maka partai PDIP hanya memperoleh satu, dari perolehan suara tersebut yang menduduki suara terbanyak adalah bapak Arwin Mega sebagai calon terpilih yang dapat duduk di lembaga Dewan Perwakilan Rakyat Kabupaten (DPRK) Aceh Tengah.

Kalau dilihat dari Jumlah suara sah mulai dari tabel 1.1 sampai dengan tabel 1.4 Partai Demokrasi Indonesia Perjuangan (PDIP) memperoleh suara sah sebanyak 15.362 suara, maka setiap daerah pemilihan partai PDIP mendapat satu kursi dan khusus di daerah pemilihan dua partai PDIP mendapat dua kursi. Dengan demikian jumlah kursi yang didapat partai PDIP pada Pemilu tahun 2019 sebanyak lima kursi dan dapat dikatakan partai PDIP sebagai pemenangnya di Kabupaten Aceh Tengah, berkat kerja keras semua tim sukses dari calon anggota legislatif dan kekompakan semua pengurus partai PDIP mulai dari DPC hingga tingkat Anak Ranting.

Dari berbagai stategi diatas bisa dilihat yang paling berpengaruh akan kemenangan sebuah partai ialah stategi komunikasi internal partai PDI-P yang mana ini mejadi tonggak baiknya dalam memaksimalkan kaderisasi dan kinerja tim sukses. Selain itu komunikasi internal partai yang baik juga berpengaruh pada suksesnya sosialisasi mengenai partai itu sedniri mulai dari ideologi sampai visi misi dari calon calon yang akan diusung oleh partai tersebut. Selain itu komunikasi yang baik akan menjalir pada setiap program yang akan dan yang sedang dilaksanakan. Sebab itu semua menjadi satu kesatuan dalam pemenangan partai PDI-P ini.

\section{Penyusunan Pemenangan PDIP Aceh Tengah}

Strategi penysusunan pemenangan PDIP Aceh Tengah ini lebih memiliki konsep modern yang memiliki tahap yang harus di lewati untuk mencapai pemenangan. Tahap yang dilakukan untuk penyusunan pemenangan ini adalah : tahap menganalisis pada situasi, kemudian formulasi, impelemntasi strategi, dan pengawasan serta evaluasi. Untuk itu, para kandidat, pada tim sukses, serta anggota partai yang harus memiliki kualitas dan kuantitas dalam menjalankan tahap tersebut. Penyusuan pemenangan ini dilakukan oleh para ketua dan anggota tim sukses dari setiap calon legislatif PDIP ini. Adanya kampanye serta kunjungan ke seluruh desa sesuai pemilihan tertentu. Kampanye dan kunjungan ini guna untuk mencari dukungan dari masyarakat agar memilih caleg tersebut.

\section{KESIMPULAN}

1. Marketing politik dan Strategi politik bagian yang telah direncana dilakukan oleh Partai Demokrasi Indonesia Perjuangan (PDIP) Kabupaten Aceh Tengah pada pemilihan umum legislative tahun 2019. Menempatkan partai demokrasi Indonesia perjuangan sebagai partai pemenang yang memiliki suara terbanyak, dan partai demokrasi Indonesia perjuangan Kabupaten Aceh Tengah memberikan kontribusi besar terhadap perubahan peningkatan kesejahteraan masyarakat dengan dijalankannya strategi dan juga rencana yang matang. Strategi ini juga tentunya harus memiliki usaha serta kerjasama yang keras, dengan adanya kerjasama yang dilakukan antara kader PDI-P Aceh Tengah dapat menghilangkan rasa egois dari para kader PDIP. Kemudian partai demokrasi Indonesia perjuangan Kabupaten Aceh tengah beserta kader nya masih memiliki tali Persaudaraan yang kuat sehingga PDI-P Aceh Tengah ini menempatkan kadernya di pimpinan legislatif DPRK Aceh tengah periode 2019-2024. Selaku pimpinan DPRK Aceh Tengah yang berasal dari PDIP, ia juga dapat merangkul seluruh kader untuk tetap menjaga kekompakan dan kebersamaan baik antara anggota legislatif, maupun bersama masyarakat.

2. Salah satu hal yang unik dari strategi pemenangan partai PDIP Aceh Tengah ini adalah adanya istilah "Ngupi Murum". Istilah ini dapat diartikan sebagai kegiatan ngopi bersama yang dilakukan oleh para kader PDIP Aceh Tengah bersama masyarakat. Tentunya dengan adanya ngopi bersama ini, kedekatan para calon legislatif PDIP Aceh Tengah bersama masyarakat akan semakin erat.

3. Menggunakan strategi pendekatan kepada masyarakat seperti memberikan penjelasan tentang idiologi partai terhadap masyarakat, meningkatkan mutu pendidikan masyarakat, meningkatkan silaturahmi dengan masyarakat. Serta strategi marketing politik. Seperti, adanya peningkatan pencarian Kaderisasi, adanya kerjasama koalisi antara partai, membentuk tim sukses, meningkatkan kualitas dan kuantitas calon legislatif, dan memperkuat struktur partai. Sehingga Partai Demokrasi Indonesia Perjuangan dan memenangkan, mempertahankan, dan memperluas serta berkontribusi besar terhadap kemenangan Partai Demokrasi Indonesia Perjuangan Kabupaten Aceh Tengah. Kemenangan suara yang dicapai dan didapat oleh partai demokrasi Indonesia perjuangan Kabupaten Aceh tengah sudah mencapai hasil sesuai dengan harapan. Seperti PDI-P Aceh Tengah berhasil mendapatkan suara terbanyak sehingga kandidat yang berasal dari PDI-P Aceh Tengah telah duduk di pimpinan, Sebagai Ketua DPRK Aceh tengah. 
REFERENSI

Aliabbas, A. (2008). Transformasi Gerakan Aceh Merdeka. Beranda Perdamaian Aceh Tiga Tahun Pasca MoU Helsinki, (April), 5-24.

Almanshur Fauzan, G. D. (2012). Metode Penelitian kualitatif. Yogyakarta: Ar-Ruzz Media.

Anggara, S. (n.d.). Sistem Politik Indonesia. Bandung: CV Pustaka Setia.

Angreni, D. K. D. (2021). Stakeholder Framing and Policy Legitimacy: Breastfeeding Policy in Aceh Province. Jurnal Manajemen Publik o Kebijakan Publik (JMPKP), 3(1), 43-58. https://doi.org/10.36085/jmpkp.v3il.1403

Budiardjo, M. (n.d.). Dasar Dasar Ilmu Politik. In 2008. Jakarta: PT Gramedia.

Bungin, burhan. (2007). Penelitian Kualitatif (Komunikasi, Ekonomi, Kebijakan Publik dan Ilmu Sosial Lainnya). Jakarta: Kencana prenada media group.

Dantes, N. (2012). Metode Penelitian. Yogyakarta: Andi.

Firmanzah. (2008). Marketing Politik: Antara Pemahaman dan Realitas. Yayasan Pustaka Obor Indonesia.

Jimly Asshiddiqie. (2015). Hukum Tata Negara dan Pilar-pilar Demokrasi. Jakarta: Sinar Grafika.

Katz S Richard dan Crotty William. (2015). Handbook Partai Politik. Bandung: Nusa Media.

KOMISI INDEPENDEN PEMILIHAN ACEH. Penetapan Jumlah Perolehan Kursi Dan Suara Minimal Bagi Partai Politik, Partai Politik Lokal Atau Gabungan Partai Politik, Gabungan Partai Politik Lokal, Gabungan Partai Politik Dan Partai Politik Lokal Dalam Pengajuan Bakal Pasangan Calon Gubernur/Waki. , (2011).

Labolo, M., \& I. T. (2015). Partai Politik dan Sistem Pemilihan Umum di Indonesia. Jakarta: PT Raja Grafindo Persada.

Less, M., Jennifer, Stromback, Jesper dan Rudd, \& C. (2009). Global Political Marketing. UK: Taylor \& Francis e-Library.

Lilleker, D. G. (Ed). (2006). The Marketing of Political Parties: Political Marketing at the 2005 British General election. New York: UBC Press.

Maurice Duverger. (2005). Sosiologi Politik. Jakarta: PT grafindo persada.

Mulyana Deddy. (2008). Metodologi Penelitian Kualitatif. Bandung: PT Remaja Rosda Karya.

Nursal, A. (2004). Political Marketing: Statgei Memenangkan Pemilu Sebuah Pendekatan Baru Kampanye Pemilihan DPR, DPD, Presiden. Jakarta: Gramedia Pustaka Utama.

Salang, S. (2007). Potret Partai Politik di Indonesia: Asesmen Terhadap Kelembagaan Kipra dan Sistem Kepartaian. Jakarta: Mitra Alembana Grafika-Forum Politisi FNS.

Schroder, P. (2010). Jakarta: Jakarta: Friendrich-Naumann.

Schroder, P. (2013). Strategi Politik. Jakarta: Stiftung.

Sugiyono. (2012). Metode Penelitian Pendidikan Pendekatan Kuantitatif, KualitatifDan ReD. Bandung: Alfabeta.

Sugiyono. (2015). Metode Penelitian Pendidikan (Pendekatan Kuantitatif, Kualitatifdan ReD). Bandung: Alfabeta.

Sutrisno, Yuningsih, N., \& A. L. (2018). Komparasi Teori Marketing Politik 4P Niffenegger dan 3P Adman Nursal. JPPUМA, 106-111.

Thaha, I. (2018). Islam dan PDI Perjuangan: Akomodasi Aspirasi Politik Umat. Jakarta: Prenamedia Group.

Wesesa, S. (2011). Political Branding and Public Relations. Jakarta: 